\title{
Faktor-Faktor yang Mempengaruhi Produksi Usahatani Jeruk Keprok di Desa Suanae Kecamatan Miomaffo Barat Kabupaten Timor Tengah Utara
}

\author{
Natalia D. Seran ${ }^{\mathrm{a}}$, dan Simon Juan Kune \\ ${ }^{a}$ Fakultas Pertanian, Universitas Timor, Kefamenanu, TTU - NTT, Indonesia. \\ ${ }^{b}$ Fakultas Pertanian, Universitas Timor, Kefamenanu, TTU - NTT, Indonesia.
}

\section{Article Info}

Article history:

Received in revised form 14 Juli 2016

Accepted 16 Juli 2016

\section{Keywords:}

Usahatani

Jeruk Keprok

Suanae
Received 7 Juli 2016

\section{Abstrak}

Desa Suanae merupakan salah satu desa yang memproduksi usahatani jeruk keprok. Penelitian ini bertujuan untuk mengetahui gambaran umum usahatani jeruk keprok dan untuk mengetahui faktor-faktor yang mempengaruhi usahatani jeruk keprok di Desa Suanae Kecamatan Miomaffo Barat Kabupaten Timor Tengah Utara. Data yang digunakan dalam penelitian ini adalah data primer yang diperoleh dari 51 responden dengan menggunakan kuesioner yang telah disusun. Metode analisis data yang digunakan dalam penelitian ini adalah metode fungsi Cobb-Douglass dengan menggunakan alat bantuan Software SpSS versi 16.0 dan data sekunder yang diperoleh dari instansi terkait Berdasarkan hasil analisis nilai signifikan $\mathrm{R}^{2}$ sebesar $96,6 \%$ dan 3,4\% adalah variabel yang tidak diteliti, uji $\mathrm{F}$ (simultan) menunjukkan bahwa $\mathrm{F}_{\text {hitung }}$ sebesar $258.021>\mathrm{F}_{\text {tabel }} 2.42$ berpengaruh nyata pada taraf 5\%, sehingga $\mathrm{H}_{1}$ diterima dan $\mathrm{H}_{0}$ ditolak sedangkan uji $\mathrm{t}$ (parsial) menunjukkan bahwa variabel luas lahan dan tingkat pendidikan berpengaruh nyata terhadap produksi jeruk keprok pada taraf 5\% sedangkan variabel benih, modal dan tenaga kerja tidak berpengaruh secara nyata terhadap produksi jeruk keprok di desa Suanae. (92016 dipublikasikan oleh Agrimor.

\section{Pendahuluan}

Sub sektor hortikultura merupakan komoditas yang cukup potensia dikembangkan secara agribisnis, karena punya nilai ekonomis dan nilai tambah cukup tinggi dibandingkan dengan komoditas lainnya. Komoditas hortikultura yang mencakup tanaman buah yakni suatu kelompok jenis tanaman hortikultura selain tanaman sayuran, tanaman bahan obat dan tanaman perkebunan yang keseluruhan atau bagian dari buahnya dapat dikonsumsi dalam keadaan segar maupun setelah diolah.

Jeruk merupakan komoditas buah yang cukup menguntungkan untuk diusahakan. Tanaman Jeruk Keprok penting untuk dikembangkan khususnya d Pulau Timor karena Jeruk Keprok merupakan komoditas unggulan yang memiliki sumber vitamin c dan mineral serta bahan baku untuk pembuatan jus. komoditas tersebut telah lama dibudidayakan dan menjadi salah satu penopang kebutuhan keluarga, bahkan di beberapa desa menjadikannya sebagai sumber mata pencarian utama ekonomi keluarga. Menurut (Wirakusumah, 2007), jeruk Keprok mengandung berbagai zat gizi dan fitonutrien dan memiliki berbagai manfaat bagi kesehatan

Desa Suanae merupakan salah satu wilayah di Kecamatan Miomaffo Bara Kabupaten Timor Tengah Utara (TTU) yang sebagian petani berusahatani jeruk Keprok. Hal ini didukung dengan produksi jeruk Keprok di Desa Suanae selama pada 4 tahun terakhir (2012-2015). Produksi Jeruk Keprok dari tahun ke tahun berfluktuasi yaitu: tahun 2012 sebanyak 33,272 ton, tahun 2013 sebanyak 22,200 ton, tahun 2014 sebanyak 22,200 ton, tahun 2015 sebanyak 25,376 ton

Berdasarkan hasil survei awal di lapangan dapat diketahui bahwa petan belum mampu untuk mengombinasikan berbagai faktor-faktor produks usahatani seperti luas lahan, benih, modal, tenaga kerja, dan tingkat pendidikan yang mana apabila dilihat masih sangat rendah. Kondisi nyata di lapangan, masyarakat petani sudah mulai menggunakan pola komersial dalam penerapan usahataninya yang ditandai dengan pada saat musim panen tiba, semua hasi panen selalu dipasarkan. Selain itu, di tengah persaingan pemasaran jeruk Keprok petani sudah mulai mengerti tentang penentuan harga jual yang mula memperhitungkan besaran biaya produksi, sehingga berdampak pada pendapatan.

Secara ekonomis, keberhasilan usahatani jeruk sangat tergantung pada jumlah input dan pemeliharaan tanaman yang diperlukan untuk menghasilkan produksi yang diharapkan (Namah, 2012). Berdasarkan hal tersebut, perlu dilakukan kajian tentang faktor-faktor yang mempengaruhi produksi usahatan jeruk Keprok di desa Suanae kecamatan Miomaffo barat kabupaten TTU dengan tujuan untuk mengetahui 1) gambaran umum usahatani jeruk Keprok; dan 2) faktor-faktor yang mempengaruhi usahatani jeruk Keprok di desa Suanae kecamatan Miomaffo Barat.

\section{Metod}

Penelitian dilaksanakan di Desa Suanae Kecamatan Miomaffo Barat dar bulan Maret-Juli 2016. Teknik pengambilan sampel dilakukan dengan metode simple random sampling yakni dari total populasi petani yang berjumlah 220 orang. Penetapan jumlah sampel penelitian ini dilakukan dengan cara menggunakan rumus slovin (Bugin, 2005) sehingga jumlah sampel yang digunakan adalah 51 responden.

Pengumpulan data dilakukan dengan metode survey. Data yang dikumpulkan berupa data primer dan sekunder. Data primer adalah data yang diperoleh dari wawancara langsung dengan responden berdasarkan pertanyaan yang telah disediakan dalam kuesioner. Sedangkan data sekunder adalah data yang diperoleh dari instansi terkait. Pengamatan dan konsep pengukuran yang dilakukan adalah 1) Identitas responden yang meliputi nama, umur, jenis kelamin, dan Pendidikan; 2) Luas lahan (ha); 3) Benih (Kg); 4) Modal yakn biaya yang dikeluarkan dalam berusahatani jeruk Keprok (Rp); 5) Tenaga kerja yaitu banyaknya curahan tenaga kerja dalam usahatani Jeruk Keprok (HKO); 6 ) Tingkat Pendidikan yaitu lamanya pendidikan formal yang dilalui oleh petan (tahun); dan 7) Produksi yaitu jumlah produksi jeruk Keprok yang diperoleh petani $(\mathrm{kg})$. Untuk menjawab tujuan pertama maka digunakan metode analisis deskriptif kualitatif, sedangkan untuk tujuan ke dua yakni untuk mengetahui faktor-faktor yang mempengaruhi produksi menggunakan metode analisis cobbdouglas sesuai petunjuk Soekartawi, (1990). Dugaan sementara penelitian ini adalah:

H1 : Terdapat pengaruh nyata dari faktor luas lahan, benih, modal, tenaga kerja, tingkat pendidikan secara bersama terhadap produksi usahatani jeruk Keprok.

Ho : Tidak terdapat pengaruh nyata dari faktor luas lahan, benih, modal, tenaga kerja, tingkat pendidikan secara bersama terhadap produksi usahatani jeruk Keprok.

Kaidah pengambilan keputusan adalah Jika $\mathrm{F}_{\text {hitung }}<\mathrm{F}_{\text {tabel }}$ maka Ho diterima dan Ha ditolak, artinya tidak terdapat pengaruh yang nyata secara keseluruhan dari semua faktor (X) terhadap produksi jeruk Keprok (Y), sedangkan jika $\mathrm{F}_{\text {hitung }}>\mathrm{F}_{\text {tabel }}$ maka Ho ditolak artinya minimal salah satu faktor produksi (X) berpengaruh nyata terhadap produksi usahatani jeruk Keprok (Y). Selanjutnya dilakukan uji “t” untuk mengetahui pengaruh parsial.

\section{Hasil dan Pembahasan}

\subsection{Gambaran Umum Lokasi Penelitian}

Desa Suanae merupakan salah satu desa yang ada di Kecamatan Miomaffo barat dengan Topografis Desa Suanae berbukit-bukit dengan dataran tersebar secara sporadis pada gugusan yang sempit diapit dataran tinggi atau perbukitan Sehingga kondisi pertanian pada Desa Suanae sangat terbatas baik pertanian lahan kering. Pertanian lahan kering banyak dilakukan pada daerah-daerah dengan kemiringan yang curam sehingga produktivitas menjadi rendah. Secara administrasi Desa Suanae terdiri dari 9 RT dan 5 RW dengan luas wilayah seluas $1010 \mathrm{~m}^{2}$. Secara geografis Desa Suanae memiliki batas-batas wilayah sebaga berikut : Sebelah Utara berbatasan dengan Kelurahan Sallu, Sebelah Selatan berbatasan dengan Desa Fatumnutu (Kabupaten TTS), Sebelah Timur berbatasan dengan Desa Fatunisuan dan Sebelah Barat berbatasan dengan Desa Kelurahan Sallu.

Keadaan iklim pada umumnya di Desa Suanae sama dengan wilayah Provinsi Nusa Tenggara Timur yang dikenal dengan 2 (dua) musim, yaitu musim kemarau dan musim hujan. Diaman musim hujan 4 bulan yaitu bulan Desember - Maret sedangkan bulan April - November adalah musim hujan. Suhu udara rata - rata sekitar pada maksimum 30 - 36 derajat Celsius dan suhu minimum 2 derajat Celsius sampai 24,5 derajat Celsius, dengan curah hujan rata - rata adalah $1.164 \mathrm{~mm} /$ tahun. Salah satu unsur penting pembentuk iklim di atas adalah curah hujan. Curah hujan sangat bervariasi. Keadaan curah hujan di wilayah ini pada umumnya sulit diramalkan, datangnya hujan dan mulainya bulan kering kadangkadang terlalu cepat dan kadang-kadang terlalu lambat.

Jumlah penduduk di Desa Suanae Kecamatan Miomaffo Barat sesuai dengan registrasi penduduk tahun 2015 adalah sebanyak 904 jiwa yang terdiri dari lakilaki sebanyak 455 jiwa dan perempuan sebanyak 449 jiwa. Dengan tingkat kepadatan penduduk rata-rata terdiri dari $311 \mathrm{KK}$.

\subsection{Gambaran Umum Usahatani Jeruk Keprok}

Kegiatan usahatani jeruk Keprok diawali dengan kegiatan persiapan lahan dan diakhiri dengan kegiatan panen dan pasca panen. Berikut akan dijelaskan tahapan-tahapan kegiatan usahatani Jeruk Keprok.

- Persiapan Lahan

Pembuatan lubang tanam dibuat 1 bulan sebelum tanam dengan ukuran lubang tanam $60 \mathrm{~cm} \times 60 \mathrm{~cm} \times 40 \mathrm{~cm}$. Dengan jarak tanam yang digunakan adalah $5 \mathrm{~m} \times 5 \mathrm{~m}$ atau $3 \mathrm{~m} \times 3 \mathrm{~m}$.

○ Benih

Benih yang digunakan pada usahatani jeruk Keprok di Desa Suanae adalah benih dari bibit varietas lokal (hasil okulasi). Berdasarkan hasil penelitian benih diperoleh dari pembibitan jeruk asam atau YC (Yapan Citrum), persiapan batang 
bawah benih tersebut kurang lebih 3 bulan dipindahkan ke bedeng kedua, perawatan dalam bedengan kedua selama 6 bulan siap diokulasi. Setelah diokulasi benih setinggi $20 \mathrm{~cm}-30 \mathrm{~cm}$ siap dipindahkan untuk ditanam di lokasi. - Pemupukan

Pemupukan perlu dilakukan untuk mengembalikan unsur hara yang telah digunakan selama pertumbuhan sampai panen. Pupuk yang digunakan berupa pupuk organik (kompos) berfungsi untuk memperbaiki struktur tanah dan meningkatkan kadar humus di dalam tanah serta menjaga kelembapan tanah. Dosis pupuk organik diberikan pada tanaman jeruk disesuaikan dengan umur tanaman. Cara pemberian yaitu: pada pemupukan awal kompos yang dicampur dengan tanah hasil galian dan dimasukkan kembali ke dalam lubang tanam.

- Pemangkasan

Pemangkasan adalah pemotongan pucuk tanaman jeruk atau cabang/ranting yang tidak teratur dan yang terlalu rimbun dengan tujuan a) Membentuk tanaman agar tidak terlalu tinggi untuk memudahkan perawatan dan pengelolaan; dan b) Membentuk percabangan agar teratur sehingga percabangan kokoh dan tanaman tumbuh seimbang. Waktu pemangkasan, sejak tanaman masih muda (di pembibitan) untuk membentuk pohon dan percabangannya, 3-4 tahun setelah tanam untuk mempertahankan tinggi pohon dan setelah panen buah untuk merangsang pertumbuhan tunas baru.

- Pengairan

Tanaman jeruk membutuhkan air yang cukup banyak dalam pertumbuhannya. Kebutuhan air untuk tanaman jeruk diperkirakan 50 liter air $/ \mathrm{m} 2$ lahan setiap bulan. Kendala yang dihadapi dalam penyediaan air adalah sering kali air tidak tersedia dalam jumlah yang cukup pada waktu yang diperlukan sehingga petani hanya mengharapkan hujan.

- Penyiangan

Penyiangan merupakan suatu kegiatan mencabut gulma yang berada di antara sela-sela tanaman. Penyiangan pada tanaman sangat dibutuhkan untuk menghilangkan/menekan pertumbuhan gulma yang menjadi pesaing pertumbuhan tanaman jeruk. Penyiangan minimal 2 kali dalam satu tahun bersamaan dengan pemberian pupuk dan pembumbunan (menimbun tanah pada pangkal tanaman).

- Pengendalian Hama dan Penyakit

Tanaman jeruk Keprok rawan terancam hama dan penyakit. Hama yang menyerang pada tanaman jeruk yaitu kutu loncat dan kutu coklat. Sedangkan penyakit tanaman adalah citrus vein phloen degnaration (CVPD) dan penyakit busuk pangkal batang. Cara pengendalian hama dan penyakit menggunakan pestisida nabati yang berupa tembakau Timor (yang sudah direndam).

- Panen dan Pasca Panen

Jeruk akan mulai memproduksi pada tahun keempat yang biasanya disebut belajar berbuah di mana jumlahnya masih sedikit. Biasanya buah tersebut dipangkas masih muda untuk merangsang produksi buah selanjutnya. Buah jeruk dapat dipanen setelah 6-9 tahun sejak saat munculnya buah. Umur panen dapat bervariasi karena perbedaan lokasi penanaman, iklim, tipe tanah dan input teknologi budidaya. Umumnya masa panen jeruk berlangsung selama 1-2 bulan.

Kegiatan pasca panen diarahkan pada usaha komersial oleh karena itu penanganan pasca panen merupakan sentuhan akhir dari buah jeruk yang menghasilkan agar buah jeruk memiliki nilai tambah dan daya tarik di dalam pemasaran.

Perlakuan pasca panen akan dapat mempertahankan mutu buah, memperpanjang umur simpan, mencegah kerusakan buah serta menghindarkan susut hasil yang terlalu banyak.

\subsection{Faktor-faktor yang Mempengaruhi Usahatani Jeruk Keprok di Desa} Suanae

a. Analisis Cobb-Douglass

Analisis yang digunakan dalam penelitian ini adalah analisis regresi berganda dalam bentuk logaritma dengan fungsi produksi cobb-douglass. Model fungsi cobb-douglass dengan metode Ordinary Least Square (OLS) terhadap produksi usahatani jeruk Keprok. Dari angka korelasi maka dilakukan model pendugaan dengan cara regresi yang hasilnya dapat dilihat pada Tabel 1.

Tabel 1. Koefisien Analisis Varians pada Produksi Usahatani Jeruk Keprok.

\begin{tabular}{lccccc}
\hline \multirow{2}{*}{ Model } & \multicolumn{2}{c}{$\begin{array}{c}\text { Unstandardized } \\
\text { Coefficients }\end{array}$} & $\begin{array}{c}\text { Standardized } \\
\text { Coefficients }\end{array}$ & \multirow{2}{*}{$\mathrm{t}$} & \multirow{2}{*}{ Sig. } \\
\cline { 2 - 4 } & $\mathrm{B}$ & Std. Error & Beta & & \\
\hline (Constant) & .780 & 1.077 & & .724 & .265 \\
X1 & .682 & .136 & .698 & 5.002 & .000 \\
X2 & .222 & .158 & .162 & 1.403 & .360 \\
X3 & .228 & .146 & .127 & 1.565 & .347 \\
X4 & .150 & .135 & .035 & 1.112 & .505 \\
X5 & .170 & .071 & .068 & 2.383 & .026 \\
\hline
\end{tabular}

Berdasarkan Tabel 1. dapat diperoleh hasil dari fungsi cobb-douglass yang dapat dihitung dengan persamaan $\mathrm{LnY}=\mathrm{Ln} 0.780+0.682 \mathrm{LnX} \mathrm{X}_{1}+$ $0.222 \operatorname{LnX}_{2}+0.228 \operatorname{Ln} X_{3}+0.150 \operatorname{Ln} X_{4}+0.170 \operatorname{Ln} X_{5}$.

\section{b. Uji F}

Koefisien regresi diuji secara serentak dengan menggunakan Anova untuk mengetahui apakah keserempakan tersebut mempunyai pengaruh yang signifikan terhadap model dapat dilihat pada Tabel 2.

\begin{tabular}{lrrrrc}
\multicolumn{6}{l}{ Tabel 2. Hasil Perhitungan Uji F. } \\
\hline \multicolumn{1}{c}{ Model } & $\begin{array}{c}\text { Jumlah } \\
\text { Kuadrat }\end{array}$ & \multicolumn{1}{c}{ DF } & $\begin{array}{c}\text { Jumlah } \\
\text { rerata }\end{array}$ & F hitung & F tabel \\
\hline Regression & 21.830 & 5 & 4.366 & 258.021 & $2.42(5 \%)$ \\
Residual & .761 & 45 & .017 & & \\
Total & 22.591 & 50 & & & \\
\hline
\end{tabular}

Data Tabel 2. menjelaskan bahwa nilai $\mathrm{F}_{\text {hitung }}>\mathrm{F}_{\text {tabel }}(258.021>2.42)$. dengan demikian, $\mathrm{H}_{0}$ ditolak dan $\mathrm{H}_{1}$ diterima pada taraf $5 \%$ artinya luas lahan, benih, modal, tenaga kerja, dan tingkat pendidikan, berpengaruh nyata terhadap usahatani jeruk Keprok.

\section{c. Koefisien Determinasi}

Koefisien Determinasi $\left(\mathrm{R}^{2}\right)$ digunakan untuk mengetahui sampai sejauh mana ketepatan atau kecocokan garis regresi yang terbentuk dalam mewakili kelompok data hasil observasi. Hasil analisis koefisien determinasi $\left(\mathrm{R}^{2}\right)$ fungsi cobb-douglass pada produksi usahatani jeruk Keprok di desa Suanae dapat dilihat pada Tabel 3.

Tabel 3. Koefisien Determinasi $\left(\mathrm{R}^{2}\right)$

\begin{tabular}{ccccc}
\hline Model & $\mathrm{R}$ & $\mathrm{R}$ Square & Adjusted R Square & $\begin{array}{c}\text { Std. Error of the } \\
\text { Estimate }\end{array}$ \\
\hline 1 & $.983^{\mathrm{a}}$ & .966 & .963 & .13008 \\
\hline
\end{tabular}

Dari Tabel 3. menunjukkan besarnya sumbangan atau kontribusi dari variabel luas lahan, benih, modal, tenaga kerja, dan tingkat pendidikan terhadap produksi usahatani jeruk Keprok yaitu sebesar 96.6\% sedangkan sisanya sebesar $3.4 \%$ yang dipengaruhi oleh variabel lain yang tidak diteliti.

\section{d. Uji t}

Uji t digunakan untuk mengetahui faktor-faktor yang mempengaruhi produksi usahatani jeruk Keprok di desa Suanae seperti luas lahan, benih, modal, tenaga kerja, dan tingkat pendidikan.

\begin{tabular}{llccccc}
\multicolumn{2}{l}{ Tabel 4. Hasil Perhitungan Uji t. } \\
\hline \multirow{2}{*}{ Model } & \multicolumn{2}{c}{$\begin{array}{c}\text { Unstandardized } \\
\text { Coefficients }\end{array}$} & $\begin{array}{c}\text { Standardized } \\
\text { Coefficients }\end{array}$ & $\begin{array}{c}\text { T } \\
\text { hitung }\end{array}$ & T tabel \\
\cline { 3 - 5 } & B & Std. Error & Beta & & \\
\hline 1 & (Constant) & .780 & 1.077 & & .724 & $1.679(5 \%)$ \\
& X1 & .682 & .136 & .698 & 5.002 & \\
X2 & .222 & .158 & .162 & 1.403 & \\
X3 & .228 & .146 & .127 & 1.565 & \\
X4 & .150 & .135 & .035 & 1.112 & \\
X5 & .170 & .071 & .068 & 2.383 & \\
\hline
\end{tabular}

a. Luas lahan $\left(\mathrm{X}_{1}\right)$

Berdasarkan hasil analisis pada Tabel 4. dapat diketahui bahwa $t_{\text {hitung }}(5.002)$ $>t_{\text {tabel }}(1.679)$ maka dapat disimpulkan bahwa luas lahan $\left(\mathrm{X}_{1}\right)$ berpengaruh nyata terhadap produksi usahatani jeruk Keprok. Hal ini berpengaruh nyata karena apabila luas lahan semakin bertambah maka produksi jeruk Keprok akan meningkat. Artinya setiap penambahan luas lahan sebesar 5\% maka akan meningkatkan produksi sebesar $0.682 \%$.

b. Benih $\left(\mathrm{X}_{2}\right)$

Berdasarkan hasil analisis pada Tabel 4. dapat diketahui bahwa $t_{\text {hitung }}(1.403)$ $<\mathrm{t}_{\text {tabel }}(1.680)$ maka dapat disimpulkan bahwa benih secara parsial dapat berpengaruh terhadap produksi jeruk Keprok tetapi tidak nyata. Hal ini disebabkan karena nilai koefisien dari penggunaan benih di Desa Suanae sebesar 0.222 menunjukkan adanya pengaruh karena nilai $t_{\text {hitung }}(1.403)<t_{\text {tabel }}(1.679)$ ini berarti setiap peningkatan benih akan meningkatkan produksi yakni setiap kenaikan jumlah benih satu-satuan akan meningkatkan produksi sebesar 0.222. c. Modal $\left(\mathrm{X}_{3}\right)$

Berdasarkan hasil analisis pada Tabel 4. diketahui bahwa $\mathrm{t}_{\text {hitung }}(1.565)<\mathrm{t}_{\text {tabel }}$ (1.679) maka dapat disimpulkan bahwa modal tidak berpengaruh secara nyata terhadap produksi jeruk Keprok. Hal ini karena modal di daerah penelitian jika bertambah maka akan meningkatkan produksi jeruk Keprok. Koefisien regresi sebesar 0.228 , artinya bahwa modal responden bertambah satu satuan maka produksi jeruk Keprok akan meningkat sebesar 0.228.

d. Tenaga Kerja $\left(\mathrm{X}_{4}\right)$

Berdasarkan hasil analisis pada Tabel 4. dapat diketahui bahwa nilai thitung (1.112) $<\mathrm{t}_{\text {tabel }}(1.679)$ maka dapat disimpulkan bahwa tenaga kerja tidak berpengaruh secara nyata terhadap produksi jeruk Keprok. Artinya bahwa apabila tenaga kerja bertambah satu maka produksi jeruk Keprok akan meningkat sebesar 0.150 .

e. Pendidikan $\left(\mathrm{X}_{5}\right)$

Berdasarkan hasil analisis pada Tabel 4. dapat diketahui bahwa nilai $\mathrm{t}_{\text {hitung }}$ (2.383) $>t_{\text {tabel }}$ (1.679) maka dapat disimpulkan bahwa tingkat pendidikan berpengaruh nyata terhadap produksi jeruk Keprok. Hal ini disebabkan nilai koefisien sebesar 0.170 menunjukkan adanya pengaruh nyata secara signifikan artinya setiap penambahan pendidikan akan meningkatkan produksi jeruk Keprok sebesar 0.170 . 


\section{Simpulan}

Usahatani jeruk Keprok di Desa Suanae umumnya meliputi persiapan lahan, benih, pemupukan, pemangkasan, pengairan, penyiangan, pengendalian hama, penyakit, panen dan pasca panen. Hasil analisis regresi uji $F$ (simultan) menunjukkan bahwa $F_{\text {hitung }}$ sebesar 258.021 $>\mathrm{F}_{\text {tabel }} 2.42$, berpengaruh nyata pada taraf 5\% sehingga $\mathrm{H}_{1}$ diterima dan $\mathrm{H}_{0}$ ditolak sedangkan uji t (parsial) menunjukkan bahwa variabel luas lahan dan tingkat pendidikan berpengaruh nyata terhadap produksi jeruk Keprok pada taraf 5\% sedangkan variabel benih, modal dan tenaga kerja tidak berpengaruh secara nyata terhadap produksi jeruk Keprok.

\section{Pustaka}

Bugin, H.M.B. 2005. Metodologi Penelitian Kuantitatif. Jakarta: Kencana. Namah, C.N. 2012. Faktor-Faktor Yang Mempengaruhi Produksi Dan Pendapatan Usahatani Jeruk Keprok Soe Di Kabupaten Timor Tengah Selatan. PARTNER, 19(1): 14-25.

Soekartawi 1990. Teori Ekonomi Produksi dengan Pokok Bahasan Analisis Fungsi Cobb-Douglas. Rajawali.

Wirakusumah, E.S. 2007. 202 Jus Buah dan Sayuran. Jakarta: Niaga Swadaya. 